\title{
Identifikasi Jumlah dan Faktor Timbulan Sampah Di Kawasan Wisata Malioboro
}

\author{
Difla Nadjih $^{1 *}$, Sujarwo Saputro ${ }^{2}$, Mukhlas Madani ${ }^{3}$ \\ ${ }^{1,}$ Universitas Cokroaminoto, ${ }^{2}$ Paguyuban Kawasan Malioboro, ${ }^{3}$ LAZ Al-Azhar DIY \\ *Penulis Koresponden, email: difnadjih@gmail.com
}

\begin{abstract}
Abstrak
Dalam upaya penyiapan Malioboro sebagai kawasan 24 jam, timbulan sampah dan limbah bisa menimbulkan menimbulkan dampak negatif. Penelitian ini bertujuan mengidentifikasi jumlah harian dan factor-faktor timbulan sampah yang ada di kawasan Malioboro khususnya di wilayah studi yakni Kawasan Gerbang Kepatihan Sayap Malioboro dengan menggunakan pendekatan fenomenologis dan rasonalistik. Dalam kajian ini mengikuti pemikiran B. Sommer (1980) tentang person center map dan place center map sehingga pergerakan pengunjung Malioboro dan aktivitas pengunjung dan pedagang PKL pada periode tertentu dengan wilayah studi tertentu, yaitu Kawasan Gerbang Kepatihan Sayap Malioboro dapat diketahui. Jenis sampah yang paling sering muncul adalah kemasan makanan dan minuman, kantong plastik, sedotan plastik, sampah puntung rokok. Volume timbulan sampah maksimal yang dapat tertampung di tempat sampah per-harinya adalah $3 \times 1,458 \mathrm{~m}^{3}=4,374 \mathrm{~m}^{3}$ per hari. Penyadaran tentang arti penting kebersihan menjadi hal penting melalui sosialisasi berupa flash mob. Saran selanjutnya maksimalisasi fungsi tempat sampah dengan pemisahan sesuai jenisnya.
\end{abstract}

Kata kunci: Malioboro, kawasan wisata, sampah, jumlah, faktor

\begin{abstract}
In preparing Malioboro as a 24-hour tourist area, garbage and waste can cause negative impacts. This study aims to identify the daily amount and factors of waste in the study area, namely the gate of Kepatihan sayap Malioboro area, using a phenomenological and rational approach. In this study, following the thoughts of B. Sommer about the person center map and place center map so that the movement of Malioboro visitors and the activities of visitors and street vendors in a certain period with a certain study area. The types of waste that most often appear are food and beverage packaging, plastic bags, plastic straws and cigarette butts. The maximum volume of waste that can be accommodated in the trash per day is $3 \times 1.458 \mathrm{~m} 3=4,374 \mathrm{~m} 3$ per day. Awareness of the importance of cleanliness is important through socialization in the form of a flash mob. The next suggestion is to maximize the function of the trash can by separating it according to its type.
\end{abstract}

Keywords: Malioboro, tourist area, waste, quantity, factors 


\section{Pendahuluan}

Pariwisata adalah industri yang kelangsungan hidupnya sangat ditentukan oleh baik buruknya lingkungan. Industry itu menjadi sangat peka terhadap kerusakan lingkungan, misalnya pencemaran oleh limbah domestik, sampah menumpuk, dan kerusakan pemandangan yang disebabkan oleh aktivitas manusia. Sebagai kawasan wisata, tentu bukan hal yang mudah menjaga reputasi Malioboro, baik dalam segi kualitas pelayanan, ketersediaan sarana dan prasarana, maupun sampai hal yang sering disepelekan, yaitu kebersihan.

Kebersihan termasuk pengelolaan persampahan suatu daerah sangat ditentukan oleh peraturan yang mendukungnya. Peraturan tersebut melibatkan wewenang dan tanggung jawab pengelola kebersihan serta partisipasi masyarakat termasuk retribusi. di kawasan Wisata pun telah menjadi perhatian pemerintah. Secara nasional Undang-Undang RI No 18 Tahun 2008 tentang Pengelolaan Sampah termasuk Peraturan Pemerintah RI Nomor 81 Tahun 2012 tentang Pengelolaan Sampah Rumah Tangga dan Sampah Sejenis Sampah Rumah Tangga. Pemerintah Daerah Propinsi DIY juga telah menurunkannya dalam Peraturan Daerah Kota Yogyakarta Nomor 10 Tahun 2012 tentang Pengelolaan Sampah (Mulasari, Husodo, dan Muhadjir 2016).

Salah satu kawasan pariwisata nasional yang sedang jadi perhatian adalah Kawasan Malioboro. Penataan Maliboro sebagai kawasan pedestrian telah berjalan. Pemerintah telah menetapkannnya dalam Peraturan Daerah Kota Yogyakarta Tentang Rencana Tata Ruang Wilayah Kota Yogyakarta yang mengatur rencana detail tata ruang kawasan Malioboro.(Tarigan 2018) Ia mengulas bahwa peraturan perundangan daerah itu berisi konsep penataan dan pembangunan Kawasan Malioboro dalam konsep teras budaya. Konsep itu mempermudah pengunjung berjalan kaki saat berkunjung di Malioboro. Dalam hal ini konsep ini ingin mewujudkan Malioboro sebagai ruang bebas motor. Orientasi kepada pejalan kaki perlu mebebaskan kawasan wisata itu bebas dari segala transportasi berasap (motor dan mobil) dan mengandalkan kendaraan berjenis lokal seperti becak dan andong dalam akses keseluruhan kawasan.

Pembebasan kawasan Malioboro yang bebas dari parkiran motor dan mobil telah terlaksana. Relokasinya secara umum relatif lancar meskipun diiringi dengan penolakan dari juru parkir dan pedagang makanan di kawasan tersebut (Yaqin dan Rosiana Puspitasari 2017). tahapan selanjutnya berupa peningkatan jam operasional menjadi 
kawasan wisata 24 jam menjadi perhatian dalam penataannya. Akan tetapi kegiatan yang ada di kawasan Malioboro juga menimbulkan dampak negatif, salah satunya adalah timbulan sampah dan limbah.

Dalam Undang-Undang Republik Indonesia, sampah merupakan sisa kegiatan manusia sehari-hari serta proses alam yang berbentuk padat.(Karyadi 2018) dari sumber yang sama, Riyadi memperlihatkan definisinya dari sisi ilmu kesehatan lingkungan. Beberapa bagian dari benda yang sudah tidak dapat digunakan lagi, tidak disenangi, tidak dipakai, ataupun sesuatuyang harus dibuang sedemekian rupa sesuai cara pengelolaan sampah sehingga tidak menimbulkan dampak yang dapat mengganggu keberlangsungan hidup.(Karyadi 2018)

Santoso, Nadjih, dan Samroni (2015) mengutip Bahar dalam menjelaskan jenis sampah yang ada. Sampah berasal dari kegiatan rumah tangga, perdagangan dan perindustrian. Sampah dari kegiatan rumah tangga secara umum terdiri dari sisa makanan, sisa pengelolaan makanan, bahan pembungkus, bermacam-macam kertas, kain bekas dan lain-lain bahan dan peralatan yang tidak terpakai dalam rumah tangga dalam berbahan bahan seperi plastik atau kertas dan bahan lainnya. Termasuk di dalamnya pakaianpakaian bekas, bahan-bahan bacaan maupun tulis, perabot rumah tangga, daun-daun dari kebun atau taman.

Pada Nadjih dan Santoso (2015) terdapat penjelasan lanjutan. Sampah dari kegiatan perdagangan berasal pasar, swalayan, pusat pertokoan, warung dan tempat jual beli lainnya. Jenisnya seperti bahan dagangan yang rusak, kertas, plastik dan daun pembungkus. Termasuk disini adalah sampah yang berasal tempat hiburan, terminal bis, stasiun kereta api dan sarana public lain. Sampah ini berupa; kertas, plastic, botol, daun dan sebagainya. sampah yang termasuk kategiri ini secara umum bersifat kering dan mudah terbakar. Sampah dari kegiatan industri, jumlah dan jenisnya sangat tergantung pada jenis dan jumlah bahan yang diolah oleh perusahaan perindustrian tersebut. Karakter bisa berbeda-beda tergantung bidang industry yang digeluti oleh perusahaan.(Santoso et al. 2015)

Bahar juga Berdasarkan bentuknya sampah dapat digolongkan pada tiga kelompok besar yaitu, sampah padat, sampah cair dan sampah gas. Karena Dasar zat kimia yang terkandung di dalamnya ada sampah organik dan an-organik. Yang keduad umumnya tidak dapat membusuk seperti sampah logam/besi, pecahan gelas, plastik sehingga penanganan perlu tindakan lnajutan yang lebih susah daripada berjenis pertama. Sampah 
organic bisa membusuk berupa sisa-sisa makanan, daun-daunan, atau buahbuahan.(Bahar 1986)

Karyadi (2018) kemudian menjelaskan bahwa timbulan sampah merupakan jumlah sampah yang timbul dari masyarakat dalam satuan volume maupun berat per kapita perhari, atau perluas bangunan atau perpanjang jalan. Timbulan itu dapat diketahui dengan melakukan sampling berdasarkan standar yang telah ditetapkan yang dinyatakan dalam satuan berat (kg/orang/hari) dan satuan volume (L/orang/hari). Datanya bisa jadi dasar dalam perencanaan dan pengkajian sistem pengelolaan persampahan.

Karakter dan pengelolaan sampah di berbagai kawasan wisata juga memiliki perbedaan.(Ermawati, Firda, dan Mukti 2018) Sampah pada wisata pantai memiliki karakter khas.(Aziz et al. 2020; Masjhoer 2018; Masjhoer dan Baiquni 2011). Wisata pegunungan juga memerlukan Tempat Pengolahan Sampah Terpadu (TPST) yang merupakan tempat dilaksanakannya kegiatan pengumpulan, pemilahan, penggunaan ulang, pendauran ulang, pengolahan, dan pemrosesan akhir.(Crisdianti 2017; Naltaru 2014)

Perhatian penuh terhadap sampah di kawasan Malioboro sebagai wisata perkotaan diperlukan. Apalagi telah memberikan dampak bagi Kota Yogyakarta sebaga kota penyumbang sampah terbesar se DIY.(Astuti et al. 2018; Habibah, Novianti, dan Saputra 2020; Mulasari et al. 2016)

Kondisi ini juga menjadi kekhususan karena, selain pengunjung,(Setiady, Putra, dan Yuriandala 2018) aktivitas PKL diduga sebagai faktor utama penyebab timbulan sampah yang terus bertambah dan menyebabkan lingkungan kawasan Malioboro kurang nyaman yang berkaitan perilaku masyarakat di lingkungannya. Menjadikan kawasan Malioboro bersih selama ini kurang berhasil, bukan karena stakeholder yang ada di sana tidak mendukung, tetapi lebih karena kurang tepat cara pandang, pendekatan, pilihan program, dan implementasi teknis serta daya dukung di lapangan. Saat ini petugas kebersihan yang disiapkan oleh UPT Malioboro hanya berjumlah 6 orang dengan waktu kerja yang terbatas.

Dari data-data yang didapatkan, nantinya akan digunakan sebagai pertimbangan dalam menentukan beberapa hal. Antara lain; jumlah petugas kebersihan, Besaran wilayah yang menjadi tanggung jawab petugas kebersihan, Peralatan dan ketrampilan petugas kebersihan. Data terkumpul juga bisa menjadi dasar mencari solusi mengatasi sumber sampah dan limbah.

Harapannya dalam prakteknya nanti, ada petugas yang selama 24 jam menjaga kebersihan setiap jengkal tanah di Malioboro. Setiap petugas diberi 
tanggung jawab menjaga kebersihan dalam luasan tertentu. Dikarenakan Sampah atau limbah adalah dampak dari sebuah aktivitas yang bersifat hilir, maka hal utama yang perlu dilakukan adalah menangani penyebab dan sumber penghasil sampahnya. Kalau tidak dilakukan pembenahan, penciptaan budaya bersih, dan kawasan bersih berkelanjutan, maka harapan menjadikan Malioboro sebagai kawasan wisata yang beroperasional 24 jam serta bersih 24 jam tidak akan pernah terwujud. Hasil dari penelitian ini diharapkan menjadi dasar pertimbangan untuk mempertahankan Malioboro Indah Tanpa Memindah.

\section{Metode}

Penelitian ini merupakan kajian awal untuk mengidentifikasi timbulan sampah yang ada di kawasan Malioboro khususnya di wilayah studi yakni Kawasan Gerbang Kepatihan Sayap Malioboro. Berdasarkan sasaran studi, maka pendekatan yang dilakukan, dan Pendekatan fenomenologis dan rasonalistik. Pendekatan fenomenologis digunakan untuk menjelaskan kompleksitas hubungan antara perilaku dengan lingkungan. Untuk penelitian ini perilaku yang diamati adalah perilaku para pedagang PKL dan perilaku pengunjung Malioboro. Pendekatan rasonalistik yaitu proses pengujian kebenaran tidak hanya melalui empiri sensual (diukur dengan indera) tapi dilanjutkan melalui pemaknaan atas empiri sensual, empiri logic (pikir) dan empiri budi (etik). Empiri sensual, empiri logic, dan empiri etik serta berdasarkan landasan teori digunakan untuk penggalian data, pemaknaan terhadap perilaku, melakukan analisis data, mempresentasikan temuan dan pembahasan (pemankaan hasil temuan). Keduanya dikutkan dengan pendekatan B. Sommer (1980) tentang person center map dan place center map yang dalam penelitian ini digunakan untuk mengetahui pergerakan pengunjung Malioboro dan aktivitas (pengunjung dan pedagang PKL) pada periode tertentu dengan wilayah studi tertentu (Kawasan Gerbang Kepatihan Sayap Malioboro).

Penelitian ini menggunakan data sekunder yang bersumber pada buku literatur, jurnal, dan sumber pustaka lain yang relevan. Untuk Data Primer dalam penelitian ini bersumber pada hasil observasi/survey di wilayah studi yang dilakukan secara terstruktur dan sistematis untuk mengidentifikasi timbulan sampah yang meliputi: lokasi sampah, jenis sampah, volume sampah, dan sumber/penyebab sampah tersebut. Observasi yang dilakukan merupakan observasi partisipasi pasif, dalam hal ini tim surveyor datang di tempat kegiatan orang yang diamati, tetapi tidak ikut terlibat dalam kegiatan tersebut. Melalui observasi ini peneliti belajar tentang perilaku pedagang PKL 
maupun pengunjung Malioboro terkait aktivitas yang berhubungan dengan sampah atau limbah yang ada di sekitar wilayah penelitian.

Kegiatan survey ini dilakukan oleh Tim peneliti dengan melibatkan mahasiswa sebagai surveyor lapangan. Hasil survey yang dilakukan akan dijadikan bahan untuk menyusun kegiatan uji coba pelayanan kebersihan 24 jam di Malioboro.

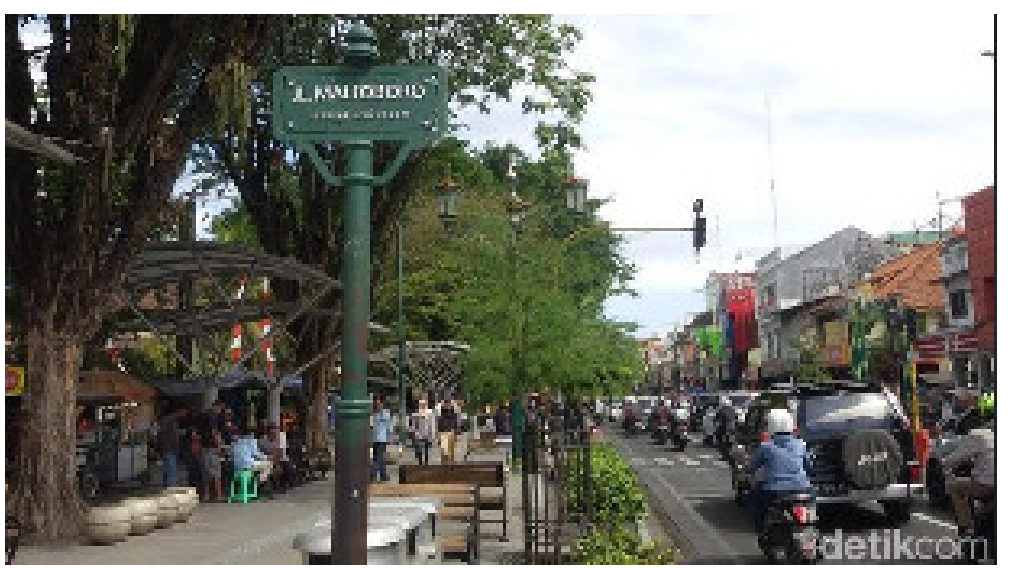

Gambar 1

Suasana Jalan Malioboro di wilayah penelitian depan kepatihan (sisi timur jalan) sumber: www.news.detik.com, 2018

Analisis data dilakukan setelah peneliti berhasil mengumpulkan seluruh data primer maupun sekunder. Dalam penelitian ini teknik analisis yang digunakan adalah secara deskriptif kualitatif. Teknik analisis data deskriptif kualitatif, digunakan dalam menganalisis dan menjelaskan kondisi lingkungan serta aktivitas pedagang PKL dan pengunjung di wilayah studi yang mengakibatkan timbulan sampah.

\section{Hasil Dan Pembahasan}

Survey untuk mengetahui kondisi persampahan di Sekitar Jalan Malioboro menggunakan studi kasus Kawasan Gerbang Kepatihan Sayap Timur J1. Malioboro, dengan panjang jalan \pm 200 meter.

Gambar 2

Peta Wilayah Penelitian 


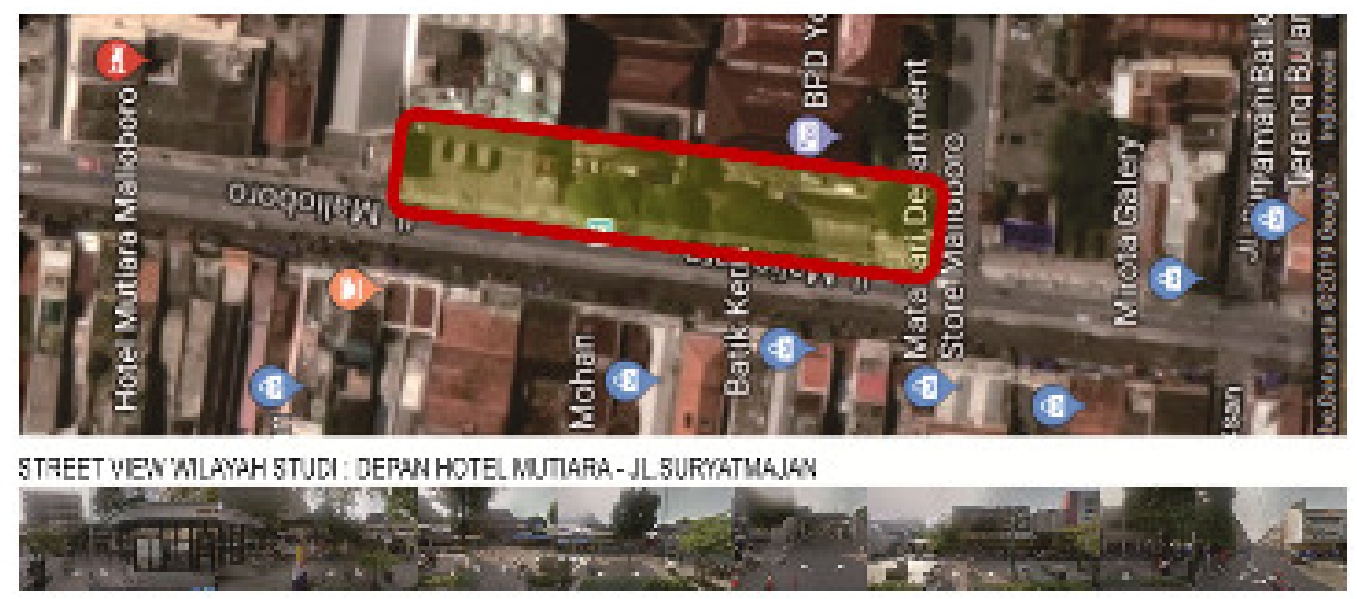

Sumber: Olahan Peneliti dari Google Map dan Google Street View, 2018

Tabel 1 Jenis Sampah dan Sumber Sampah di Wilayah Studi

\begin{tabular}{|c|c|c|c|c|c|}
\hline No. & & is Sampah & $\begin{array}{l}\text { Sumber } \\
\text { Sampah }\end{array}$ & Lokasi & kume \\
\hline 1. & $\begin{array}{l}\text { Sampah } \\
\text { Organik }\end{array}$ & $\begin{array}{llr}\text { a. } & \text { dedaunan } \\
\text { b. } & \text { sampah } \\
& \text { makanan }\end{array}$ & $\begin{array}{l}\text { - PKL } \\
\text { - Pengunjung }\end{array}$ & $\begin{array}{l}\text { a. Di sekitar } \\
\text { pedestrian } \\
\text { p. tempah } \\
\text { sampah yang } \\
\text { tersedia }\end{array}$ & $\min \quad y-4$ \\
\hline 2. & $\begin{array}{l}\text { Sampah } \\
\text { Anorgnaik }\end{array}$ & $\begin{array}{l}\text { - Botol minuman } \\
\text { - bungkus makanan } \\
\text { - kantong plastik } \\
\text { - putung rokok } \\
\text { - sedotan } \\
\text { - kertas }\end{array}$ & $\begin{array}{l}\text { - PKL } \\
\text { - Pengunjung }\end{array}$ & $\begin{array}{l}\text { - di sekitar } \\
\text { lubang pohon } \\
\text { - di tempat } \\
\text { duduk } \\
\text { - di sekitar bak } \\
\text { sampah dan } \\
\text { tanaman }\end{array}$ & 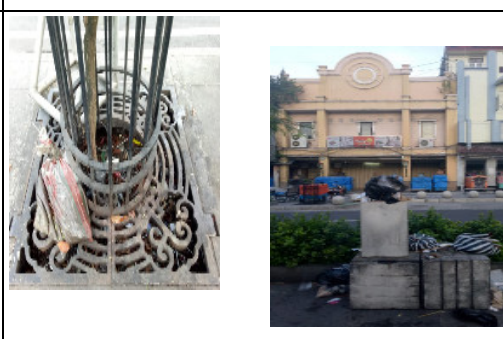 \\
\hline 3. & Limbah & $\begin{array}{l}\text { - Sisa minuman } \\
\text { - limbah cair bekas } \\
\text { cucian. }\end{array}$ & PKL & 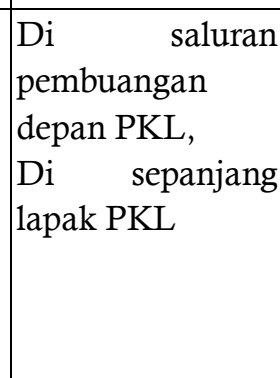 & 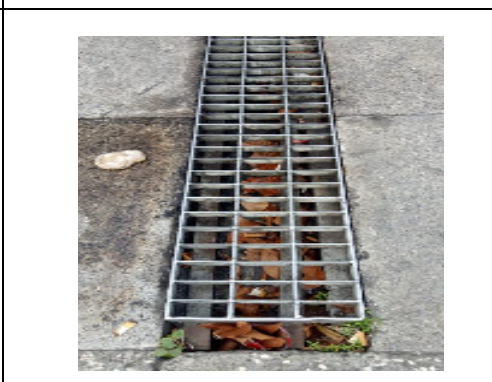 \\
\hline
\end{tabular}

Hasil di atas berdasarkan survey yang telah dilakukan oleh tim surveyor pada tanggal 16,17, 23, dan 24 Maret 2019 sesuai dengan waktu yang telah ditetapkan yakni terbagi dalam empat waktu Pukul 05.50 WIB s/d 06.30 WIB (Pagi), Pukul 12.00 WIB s/d 13.30 WIB (Siang), Pukul 16.30 WIB s/d 17.30 WIB (Sore), dan Pukul 21.00 WIB s/d 22.00 WIB (Malam). 
Selain itu, Pengamatan menunjukkan bahwa perilaku pengunjung dan pedagang PKL dalam membuang sampah membuat sampah tercampur tidak sesuai dengan jenisnya. Padahal tempat sampah yang tersedia sudah ada simbol jenis sampahnya. Selain itu, para pedagan PKL khususnya yang menjual makanan dan minuman tidak memiliki tempat sampah sendiri, sehingga ikut membuang sisa makanan dan minuman di tempat sampah yang tersedia di pedestrian.

Limbah makanan PKL membuat area Malioboro berbau kurang sedap. Oleh sebab itu direkomendasikan untuk menyediakan tempat sampah khusus bagi para pedagang PKL yang pengelolaannya dikembalikan kepada para pedagang tersebut, yang tempatnya dipisah dengan tempat sampah untuk pengunjung.

Berdasarkan ragam jenis sampah yang ditemukan di wilayah amatan, berikut ini adalah beberapa jenis sampah yang paling banyak ditemukan. Paling banyak adalah kemasan makanan dan minuman. Dari Our World in Data, yang mengklasifikasikan berbagai jenis sampah_yang paling banyak ada di dunia Sepanjang 2015, Urutan teratas ditempati oleh sektor kemasan makanan dan minuman dengan total lebih dari 146 juta ton per tahun. ${ }^{1}$ urutan kedua berupa kantong plastik. Sampah terbanyak ketiga di Malioboro sedotan plastik. Data World Bank 2018 menyebut sampah sedotan plastik termasuk ke dalam lima jenis sampah yang paling banyak ditemukan di Indonesia. Organisasi Divers Clean Action (DCA) menyebut bahwa sampah sedotan plastik di Indonesia mencapai lebih dari 93,2 juta per hari. Untuk diketahui, sedotan plastik membutuhkan waktu selama 500 tahun untuk bisa terurai secara alami. Putung Rokok menjadi sampah yang juga banyak dijumpai di kawasan wisata tersebut. Elizabeth Smith yang bekerja di kebijakan pengendalian tembakau di Universitas California San Francisco menjelaskan bahwa, "Banyak perokok berasumsi penyaring rokok terbuat dari bahan yang bisa terbiodegradasi atau bisa diolah. Padahal, filter rokok terbuat dari selulosa asetat (jenis plastik yang butuh sekitar satu dekade untuk bisa terurai)."(Anon n.d.)

Dari kuantitas sampah harian yang ditemukan, Malioboro telah menjadi salah satu destinasi wisata unggulan sekaligus penyumbang volume sampah terbesar di Kota Yogyakarta. Sampah yang dihasilkan kawasan Malioboro sekitar 60-70 ton per hari, sedangkan jalan Malioboro mencapai 6 ton perharinya.(Anon n.d.)

Penghitungan volume sampah yang terdapat di wilatah studi/ amatan dihitung berdasarkan volume timbulan sampah yang terdapat baik di tempat 
sampah dan yang tersebar di tempat selain tempat sampah. Adapun volume sampah yang tersebar di luar tempat sampah diasumsikan sebesar 5\% yang ada di tempat sampah. Angka 5\% diambil melihat kondisi faktual di lapangan saat dilakukan pengamatan. Angka tersebut bisa berubah seiring dengan potensi peningkatan produksi sampah setiap harinya.

Jumlah tempat sampah yang tersedia di wilayah amatan sebanyak 9 tempat sampah permanen, dan 1 tempat sampah keranjang (di dekat halte bis Trans Jogja). Volume maksimal untuk satu tempat sampah permanen $\pm 0,162$ $\mathrm{m}^{3}$. sehingga jika seluruh tempat sampah permanen terisi penuh dengan sampah maka volume timbulan sampah maksimal adalah $9 \times 0,162 \mathrm{~m}^{3}=$ $1,458 \mathrm{~m}^{3}$. Dalam pengelolaannya, sampah diangkut menggunakan gerobak dalam tiga shift yakni pagi jam 04.00 wib, siang jam 12.00 wib, dan malam jam 18.00 wib. Sehingga volume timbulan sampah maksimal yang dapat tertampung di tempat sampah per-harinya adalah $3 \times 1,458 \mathrm{~m}^{3}=4,374 \mathrm{~m}^{3}$.

Sedangkan untuk tempat sampah keranjang volumenya $\pm 30 \%$ dari tempat sampah permanen yakni $30 \% \times 4,374 \mathrm{~m}^{3}=1,312 \mathrm{~m}^{3}$ per hari. Dengan demikian volume timbulan sampah yang diwadahi tempat sampah perhari sebanyak $5,686 \mathrm{~m}^{3}$.

Berdasarkan asumsi untuk sampah yang ada di luar tempat sampah yakni $5 \%$ dari volume sampah yang diwadahi tempat sampah, maka volume sampah yang tersebar sebanyak $5 \%$ x 5,686 $\mathrm{m}^{3}=0,284 \mathrm{~m}^{3}$. Sehingga jumlah volume timbulan sampah di wilayah amatan per-harinya sebesar $\pm 5,97 \mathrm{~m}^{3}$ atau 5970 liter. Volume timbulan sampah ini hanya di wilayah studi sepanjang 200 meter dan hanya satu sisi jalan (sisi timur), sedangkan pengangkutan dengan gerobak yang dilakukan petugas kebersihan biasanya memuat timbulan sampah dari kedua sisi jalan Malioboro. Salah satu kekurangan dalam pengamatan ini adalah belum dipertimbangkannya jalur pedestrian sisi barat jalan Malioboro yang saat ini kondisinya juga sudah terdapat tempat duduk serta tempat sampah. Sehingga dalam perhitungan volume timbulan sampah seharusnya juga dihitung sesuai dengan kondisi faktual di lapangan.

Volume timbulan sampah ini, nantinya menjadi dasar pertimbangan untuk menentukan berapa kali pengangkutan sebaiknya dilakukan oleh petugas kebersihan, mengingat saat ini pengangkutan sampah dilakukan menggunakan satu gerobak sampah yang didorong manual oleh petugas. Rute pengangkutan sampah oleh petugas adalah dari arah utara menyisir tempat sampah di sisi barat Jalan Malioboro, kemudian sampai di perempatan J1.Suryatmajan gerobak menyeberang ke sisi timur Jalan 
Malioboro untuk menyisir dan mengangkut sampah yang ada di sisi timur jalan Malioboro.

Dimensi gerobak sampah yang umum di pasaran yakni panjang 1,2 meter, lebar $80 \mathrm{~cm}$, dan tinggi $70 \mathrm{~cm}$, volume maksimal gerobak sekali angkut $0,672 \mathrm{~m}^{3}$. Adapun bahan dari plat besi, siku, pipa besi beton $6 \mathrm{~mm}$.

Gambar 3

Contoh Gerobak Sampah

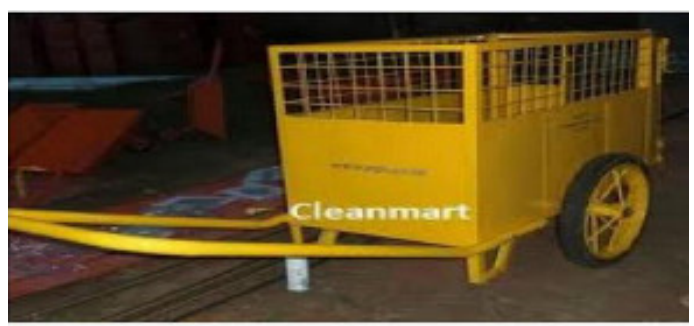

Gerobak sampah

Spesifikasi

Ukuran panjang.lebar,tinggi

$1,20 \mathrm{~m} \times 80 \mathrm{~cm} \times 70 \mathrm{~cm}$

Bahan : Plat, Siku,Pipa,besi beton $6 \mathrm{~mm}$

Timbulan sampah kemudian bisa diketahui lebih disebabkan kepada perilaku para pengunjung dan Pedagang kaki lima di kawasan wisata Malioboro. Di musim dan hari yang ramai, jumlah sampah pun mengalami peningkatan. Hal yang dibenarkan dalam penelitian Astuti dkk. (2018) Jumlah sampah semakin hari semakin meningkat seiring dengan jumlah penduduk dan pola konsumsi masyarakat. perilaku masyarakat dalam kehidupan sosial dan ekonomi akan berubah seiring banyaknya pendatang di kawasan industri. Perubahan itu seperti berkurangnya rasa solidaritas dan pola hidup yang lebih konsumtif. Hal ini memicu peningkatan produksi sampah dan sifat acuh terhadap lingkungan sekitar. Peningkatan jumlah sampah akan menjadi suatu potensi bencana darurat sampah apabila tidak disertai dengan pengelolaan yang baik.

Faktor kesadaran masyarakat juga menjadi sorotan Mulasari dkk. (2016) permasalahan sampah di KotaYogyakarta terkait kurangnya kesadaran masyarakat dalam mensikapi dan mengelola sampah. Kesadaran lingkungan hidup hendaknya sudah dikenalkan sejak dini (Imroatun 2015; Musaropah 2014), namun masyarakat masih banyak yang membuang sampah sembarangan disungai. Bahkan ketika sudah disediakan tempat pembuangan sampah sementara (TPSS) di lingkungannya,masyarakat masih tidak tertib dalam waktu ataupun tempat membuang sampahnya. Konsep3R (reuse,replace,recycle) tidak diterapkan dengan baik dan perilaku membuang sampah sembarangan masih tinggi. Oleh karenanya, peningkatan sosialisasi 
tentang pembuangan sampah menjadi prioritas penting di berbagai kawasan wisata untuk menjaga kebersihannya.(Aziz et al. 2020; Ermawati, et al. 2018; Karyadi 2018; Masjhoer 2018; Tarigan 2018)

\section{Kesimpulan Dan Saran}

Sebagai kawasan wisata yang dikunjungi oleh berbagai macam orang, sampah yang terdapat di area survey meliputi kategori sampah organik, sampah anorganik, serta limbah. Dari ketiga jenis itu, Jenis sampah yang paling sering muncul adalah kemasan makanan dan minuman, kantong plastik, sedotan plastik, sampah puntung rokok. Volume timbulan sampah mencapai maksimal untuk tempat sampah permanen berukuran $9 \times 0,162 \mathrm{~m}^{3}$ $=1,458 \mathrm{~m}^{3}$. Sehingga volume timbulan sampah maksimal yang dapat tertampung di tempat sampah per-harinya adalah $3 \times 1,458 \mathrm{~m}^{3}=4,374 \mathrm{~m}^{3}$ per hari. Pengangkutan timbulan sampah masih sangat kurang memadai baik dari sisi volume armada angkut (gerobak), maupun frekuensi pengangkutan. pemisahan jenis sampah dengan adanya tempat sampah yang telah diberi simbol tertentu tidak berfungsi. Tempat sampah keranjang volumenya $\pm 30 \%$ dari tempat sampah permanen yakni $30 \% \times 4,374 \mathrm{~m}^{3}=1,312 \mathrm{~m}^{3}$ per hari. Volume sampah yang tersebar sebanyak $5 \% \times 5,686 \mathrm{~m}^{3}=0,284 \mathrm{~m}^{3}$. Sehingga jumlah volume timbulan sampah di wilayah amatan per-harinya sebesar \pm $5,97 \mathrm{~m}^{3}$ atau 5970 liter.

Agar pemasalahan samapah bisa terkontrol, sosialisasi dalam bentuk flash mob di titik-titik yang ramai pengunjung, pada saat musim liburan untuk menarik perhatian pengunjung dan menjelaskan pentingnya kebersihan. Untuk memaksimalkan fungsi tempat sampah dan pemisahan sampah sesuai jenisnya, berikut ini alternatif desain yang diajukan: menambahkan tulisan jenis sampah yang dimaksud (sampah organik, sampah anorganik, sampah B3), serta menambahkan keterangan simbol jenis sampah di sisi depan tempat sampah dengan warna sesuai jenis sampah, yakni: sampah organik (warna hijau), sampah anorganik (warna kuning), serta sampah B3 (warna merah). Alternative kedua.memberi warna/cat pada sisi atas tempat lubang sampah sesuai dengan warna jenis sampah yakni: sampah organik (warna hijau), sampah anorganik (warna kuning), serta sampah B3 (warna merah) serta memberi tulisan jenis sampah di bagian atas tulisan JOGJA, dengan ukiran. Penellitian lanjutan masih bisa dilakukan. Penelitan samapa di Malioboro masih memerlukan penenltian populatif. Keterbatasan disini terletak pada wilayah depan daerah Kepatihan sisi Timur jalan dengan panjang kurang lebih 200 meter. 


\section{Ucapan Terima Kasih}

Penelitian merupakan kerjasama LDPM UCY, Paguyuban Kawasan Malioboro, FLKM, LAZ al-Azhar DIY dan APKLI DIY. Penelitian ini juga dibantu oleh para Mahasiswa UCY; Yosef Satrianus Budiman, Syafaat Taslim, Ardiansyah, Adviansyah Huda Suharto, Rejebmamet, Elvas Maulana, Isma'il Achmad, Nia Nurul Umami, Sulaeman Waeduramae, Zaenul Masrurodin, Gunawan, Puput Puspita Dewi, Amin Rais. Para Penulis mengucapkan terima kasih atas kerja sama dan bantuannya. Meski demikian, penelitian ini tidak mencerminkan pendapat dan pandangan kelembagaan dari masing-masing pihak bekerja sama sehingga menjadi tanggung jawab pribadi para penulis secara penuh.

\section{Daftar Pustaka}

Anon. n.d. "Dari Plastik Hingga Puntung Rokok, Ini 5 Jenis Sampah Terbanyak di Bumi - Semua Halaman - National Geographic." Diambil (https://nationalgeographic.grid.id/read/131645261/dari-plastikhingga-puntung-rokok-ini-5-jenis-sampah-terbanyak-di-bumi?page=all).

Anon. n.d. "Liburan Lebaran, Volume Sampah Terbanyak Kawasan Malioboro." Diambil (https://tegas.co/2017/07/03/liburan-lebaranvolume-sampah-terbanyak-kawasan-malioboro/).

Astuti, Farida Afriani, Dina Asrifah, Ika Wahyuning Widiarti, Ayu Utami, Dian Hudawan Santoso, Jurusan Teknik Lingkungan, dan Fakultas Teknologi Lingkungan. 2018. "Identifikasi Persepsi Pola Perlakuan Sampah Oleh Masyarakat Dalam Meningkatkan Efektifitas Pengelolaan Sampah Kota Yogyakarta." Jurnal Science Tech 4(2):59. doi: 10.30738/SCIENCE TECH.V4I2.2678.

Aziz, Rizki, Yommi Dewilda, Hafizhul Khair, dan Mikel Faklin. 2020. "Pengembangan Sistem Pengelolaan Sampah Kawasan Wisata Pantai Kota Pariaman dengan Pendekatan Reduce-Reuse-Recycle." Jurnal Serambi Engineering 5(3). doi: 10.32672/jse.v5i3.2141.

Bahar, Y. H. 1986. Teknologi Penanganan Sampah. Jakarta: PT. Wacana Utama Pramesti.

Crisdianti, Vera. 2017. "Alternatif Pengelolaan Sampah di Kawasan Wisata Laut Pasir Taman Nasional Bromo Tengger Semeru." Bogor Agricultural University (IPB), Bogor.

Ermawati, Eka Afrida, Firda Rachma Amalia, dan Masetya Mukti. 2018. "Analisis Strategi Pengelolaan Sampah di Tiga Lokasi Wisata Kabupaten Banyuwangi." Journal of Tourism and Creativity 2(1):25.

Ermawati, Eka Afrida, Rachma Amalia Firda, dan Masetya Mukti. 2018. "Analisis Strategi Pengelolaan Sampah di Tiga Lokasi Wisata Kabupaten Banyuwangi." Journal of Tourism and Creativity 2(1). doi: 10.19184/JTC.V2I1.13838.

Habibah, Erpin, Febi Novianti, dan Hanafi Saputra. 2020. "Analisis Terhadap Faktor Yang Berpengaruh Terhadap Penerapan Kebijakan Pengelolaan Sampah Di Yogyakarta Menggunakan Pemodelan Sistem." 
Jurnal Analisa Sosiologi 9(0). doi: 10.20961/jas.v9i0.39809.

Imroatun, Imroatun. 2015. "Masjid dan Pengembangan Wawasan Anak Usia

Dini dalam Pelestarian Lingkungan Hidup Nasional." Ulumuddin: Jurnal Ilmu-ilmu Keislaman 5(1):21-28.

Karyadi, Ryan Setyawan Husni. 2018. "AnalisisTimbulan Dan Komposisi Sampah di Kawasan Wisata Candi Sambisari Dan Taman Kaliurang Sleman DI Yogyakarta Di." Universitas Islam Indonesia, Yogyakarta.

Masjhoer, Jussac Maulana. 2018. "Partisipasi Pelaku Usaha Pariwisata dalam Pengelolaan Sampah di Pantai Pulang Sawal, Kabupaten Gunungkidul, Yogyakarta." Jurnal Pariwisata Terapan 2(2):122. doi: 10.22146/jpt.43179.

Masjhoer, Jussac Maulana, dan H. M. Baiquni. 2011. "Kajian Pengelolaan Sampah Di Kawasan Wisata Pantai Parangtritis Kabupaten Bantul." Universitas Gadjah Mada, Yogyakarta.

Mulasari, Surahma Asti, Adi Heru Husodo, dan Noeng Muhadjir. 2016. "Analisis Situasi Permasalahan Sampah Kota Yogyakarta Dan Kebijakan Penanggulangannya." Jurnal Kesehatan Masyarakat 11(2):259. doi: 10.15294/kemas.v11i2.3989.

Musaropah, Umi. 2014. "Pendidikan Agama Islam Berwawasan Lingkungan Pada Anak Usia Dini (Studi Kasus di Pos PAUD Ananda Nologaten)." Ulumuddin: Jurnal Ilmu-ilmu Keislaman 4(1):48-57.

Nadjih, Difla, dan F. Setiawan Santoso. 2015. "Sosialisasi Fikih Lingkungan Usulan Pemberdayaan Majelis Taklim Di Desa Nelayan." Ulumuddin: Jurnal Ilmu-ilmu Keislaman 5(2):65-73.

Naltaru, Merlin. 2014. "Perencanaan Sistem Pengelolaan Sampah Di Kawasan Wisata Bukit Kelam Kabupaten Sintang." Jurnal Teknologi Lingkungan Lahan Basah 2(1). doi: 10.26418/jtllb.v2i1.6623.

Santoso, Fattah Setiawan, Diflah Nadjih, dan Imam Samroni. 2015. Penguatan Budaya Ramah Lingkungan Berbasis Fikih Di Kampung Nelayan Wilayah Poncosari Srandakan Bantul-DIY, Laporan Akademik Program Bantuan Peningkatan Mutu Pengabdian Kepada Masyarakat. Jakarta.

Setiady, Irvan, Purnama Putra, dan Yebi Yuriandala. 2018. Analisis Sikap Dan Persepsi Wisatawan Dalam Mengelola Sampah Di Kawasan Pariwisata Kota Yogyakarta (Studi Kasus Di Tugu Yogyakarta dan Malioboro) Study of Tourist Attitudes and Perceptions in Managing Waste in Tourism Yogyakarta (Case Study Tugu Yogyakart. Yogyakarta.

Tarigan, Mustafa Kamal. 2018. "Pendidikan Agama Islam, non-formal, guru, kompetensi social, wilaya pesisir Mewujudkan Pembangunan Dan Penataan Wilayah Malioboro Sebagai Wilayah Wisata Ramah Lingkungan." JURNAL PENELITIAN PENDIDIKAN SOSIAL HUMANIORA 3(1):305-11. doi: 10.32696/jp2sh.v3i1.91.

Yaqin, Ilmal, dan Dyah Rosiana Puspitasari. 2017. "Pelaksanaan Peraturan Daerah Kota Yogyakarta No. 18 Tahun 2009 Tentang Penyelenggaraan Perparkiran Ditinjau Dari Aspek Sosiologis." in Prosiding Seminar Nasional Multidisiplin Ilmu. Vol. 0. 
Difla Nadjih, Sujarwo Saputro, Mukhlas Madani 